\title{
A Song in the Night
}

\author{
Reviewed by Anthony David
}

\begin{abstract}
A pertormance based on the lite and work of the 19th century poet John Clare, 8 October 1993. Witten by Roger Fitth, directed by Patilick Garland, staring Freddile Jones
\end{abstract}

"If life had a second edition, how I would correct the proofs". Who would not identify with this poignant supplication taken from the work of 'peasant poet' John Clare, the bicentenary of whose death was marked by a one-man show in Westminster Abbey last year? Clare was born two years before Keats but their work and fates could not have been more different. Clare was born in Northamptonshire, the son of an east London stableman - a member of the agricultural working class. He was an inspired poet, drawing from the power of the natural world, landscape, birdsong and romantic love but removed from the excesses of the academic and romantic poetry of the time. His life was not just a struggle to gain recognition and patronage, part of any poet's curriculum vitae, but had two additional burdens. The first was political: his love of the land and itinerant lifestyle conflicted sharply with government policy to appropriate land and gain control over its people enshrined in the General Enclosures Act of 1843. He became almost a refugee in his own country. The second was mental illness-proceeds of the performance went to the National Schizophrenia Fellowship.

In 1837, the distraught Clare decided to spend time at the High Beech asylum in Essex. It appears that he suffered from delusions of grandeur and persecution. He described his experience as being captive among the Babylonians. He believed he was such luminaries as Lord Byron, a contemporary, and Lord Nelson. After four years, Clare returned to his home to find that the major love of his life, Mary Joyce had died three years previously. He was soon committed, this time to St Andrew's Asylum in Northampton where he spent the next 22 years until his death aged 71 . He hated being in what he nicknamed the Bastille. Deprived of his beloved countryside, he wrote to his son "My eyes have got no pupils". For Clare there was "no place like home" - perhaps he coined the phrase.

Actor Freddie Jones cried out these words in the echoic gloom of Westminster Abbey to the accompaniment of eerie violin music. The effect

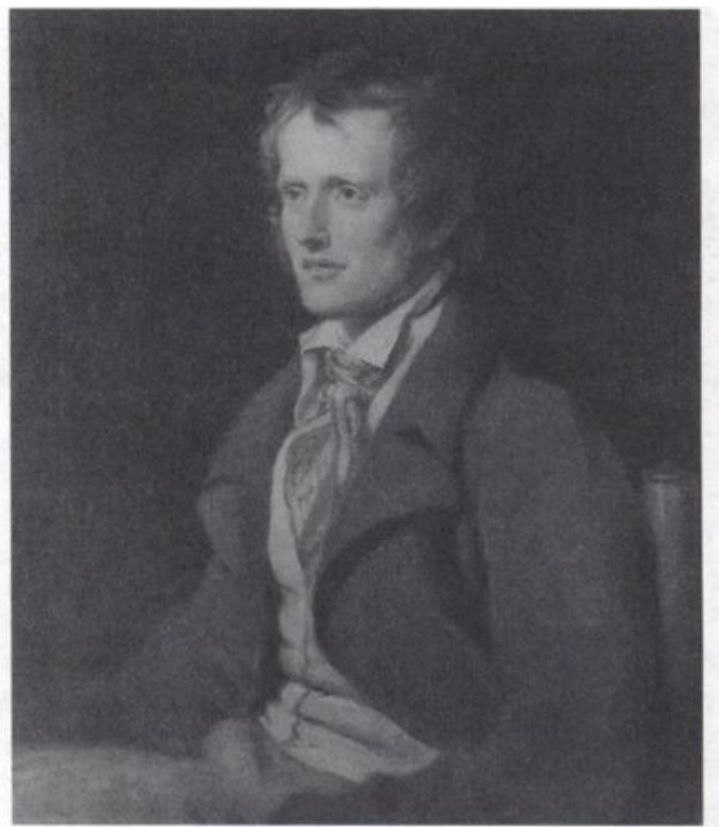

John Clare, copyright National Portrait Gallery

was moving, frightening and hypnotic. My mind began to wander, as I mused on the ironies of Clare's grave in Poets Corner-there since 1989 -jostling with Byron, prayed over by Gerard Manley Hopkins, sneered at by T.S. Eliot.

And what of the madness-genius story? Tragedy seemed to add an extra layer of meaning to these poems - but their controlled power was uncontaminated by thought disorder and the rest. It would be a shame if Clare became most famous for being mad in the way that Nijinsky has. More people know about John Betjeman's Parkinson's disease than his poetry and who knows what Lou Gehrig did before he got Lou Gehrig's disease? Nevertheless if this is the only way the public can be persuaded that people with schizophrenia retain their humanity and their capacity for love, that they are not all homicidal criminals, John Clare will not have died in vain.

Anthony David, Senior Lecturer,

Institute of Psychiatry, London SE5 8AF 